\title{
A research on the change in the nutritional habits of consumers before and after covid-19
}

\author{
Tüketicilerin koronavirus (covid-19) öncesi ve \\ sonrası beslenme alışkanlıklarındaki değişim \\ üzerine bir araştırma
}

Gönderim Tarihi / Received : 08.09.2020

Kabul Tarihi / Accepted : : 08.01.2021

Doi: https://doi.org/10.31795/baunsobed.792317

\section{Mehmet Akif ŞEN*1 Mehmet ŞIMŞEK²}

\begin{abstract}
This study was conducted to determine the changes in the nutritional habits of consumers before and after Coronavirus (COVID-19). The research data were obtained through an online questionnaire. According to the results of the frequency analysis conducted on the data obtained from 1258 participants in total, it was observed that there was a significant change in the nutritional habits of consumers. It was revealed that the highest of these behavioural changes occurred in the behaviour of ordering takeout, consuming fast food, making bread at home, consuming foods that strengthen the immune system, not skipping meals and thinking that you have a balanced diet. According to the results of $\mathrm{T}$ test and ANOVA test conducted to see whether these changes differ based on the demographic characteristics of the participants, it was determined that the change in the nutritional habits of the participants differed based on gender, age, educational background and income.
\end{abstract}

Keywords: Coronavirus, Nutritional behaviour, Nutritional habits.

ÖZ: Bu çalışma tüketicilerin Koronavirus (COVID-19) öncesi ve sonrasında beslenme alışkanlıklarındaki değişimi belirlemek amacıyla yapılmıştır. Çalışmanın verileri internet üzerinden online doldurulan bir anket yoluyla elde edilmiştir. Toplamda 1258 katılımcıdan elde edilen veriler üzerinde yapılan frekans analizi sonuçlarına göre tüketicilerin beslenme alışkanlıklarında önemli değişimin gerçekleştiği görülmüştür. Söz konusu davranış deği

\footnotetext{
*Sorumlu Yazar / Corresponding Author

${ }^{1}$ Dr. Öğr. Üyesi, Giresun Üniversitesi/Turizm Fakültesi/Gastronomi ve Mutfak Sanatları Bölümü/ Gastronomi ve Mutfak Sanatları Anabilim Dalı, mehmetakifsenn@gmail.com, https://orcid.org/0000-0002-2987-8074

${ }^{2}$ Dr. Öğr. Üyesi, Giresun Üniversitesi/Turizm Fakültesi/Gastronomi ve Mutfak Sanatları Bölümü/ Gastronomi ve Mutfak Sanatları Anabilim Dalı, mehmet.simsek@giresun.edu.tr, https://orcid.org/0000-0002-7558-5010
} 
şimlerinden en yüksek olanlarının dişarıdan paket yemek siparişi verme, fast food tüketme, evde ekmek yapma, bağışıklık sistemini güçlendirici gıdalar tüketme, öğün atlamama ve dengeli beslendiğini düşünme davranışlarında gerçekleştiği görülmüştür. Bu değişimlerin katılımcıların demografik özelliklerine göre farklılaşıp farklılaşmadığına yönelik yapılan $\mathrm{T}$ testi ve anova testi analizi sonuçlarına göre katılımcıların beslenme alışkanlıklarındaki değişimin cinsiyet, yaş, eğitim durumu ve gelirlerine göre farklılaştığ tespit edilmiştir.

Anahtar Kelimeler: Koronavirus, Beslenme davranışı, Beslenme alışkanlığı. 


\section{GENIŞLETILLMIŞ ÖZET}

\section{Literatür taraması}

Bilindiği üzere COVID-19 Aralık 2019 tarihinde önce Çin'de başlayan Ocak 2020 itibarıyla ise hızla ve kontrol edilemez bir şekilde tüm dünyaya yayılmaya başlayan yeni ve tehlikeli bir virüs türüdür. 2019 yılının Aralık ayında ortaya çıkan COVID-19'un ilk kaynağının Wuhan'da ki bir deniz ürünleri pazarı olduğu fakat bulaşmanın insandan insana damlacık yoluyla veya temas yoluyla gerçekleştiği belirtilmektedir. Dünya sağlık örgütü tarafından salgın hastalık olarak kabul edilen COVID-19'un yayılımını durdurmada ülkeler oldukça zorlanmaktadırlar. Yayılımı durdurmaya yönelik olarak dünyanın birçok ülkesinde olduğu gibi Türkiye'de de bazı radikal tedbirler alınmış ve alınmaya da devam edilmektedir. Bu tedbirlerin başında sokağa çıkma yasağı, virüsün yaygın olduğu yerlerin karantina altına alınması, birçok işyerinin geçici olarak kapatılması, sosyal izolasyon, herhangi bir nesneye ve/veya insana temas etmeme ve sosyal mesafe gelmektedir. Dünyanın birçok ülkesinde olduğu gibi ülkemizde de uygulanmaya başlayan bu tedbirler sonucunda insanların büyük çoğunluğu evlerine kapanmak durumunda kalmışlardır. Bu süreçte birçok kişinin ekonomik, sosyal ve psikolojik durumlarında değişimlerin olması kaçınılmazdır. Bu değişimlerden birinin de beslenme alışkanlıkları konusunda olduğu düşünülmektedir.

Stresin etkilerine yönelik yapılan çalışmalarda stresin organizmanın fiziksel ve psikolojik sınırlarının zorlanması ve tehdit edilmesi ile ortaya çıkan bir durum olması sebebiyle beslenme alışkanlığıyla yakından ilişkili olduğu savunulmaktadır. Konuya yönelik yapılan bazı araştırmalar stres dönemlerinde insan vücudunun kendini toparlayabilme arayışının sonucu olarak belirli gıda türlerine karşı yoğun ilgi duyduğunu ileri sürmektedir. Bu gıdaların daha çok yüksek kalorili ve şekerli gıdalar olduğu ve bunun da vücudun serotonin hormonu üretimi ile ilişkili olduğu savunulmaktadır. Bu sebepten ötürü bazı bireylerin stres altındayken, fizyolojik rahatlık yerine psikolojik rahatlığg seçerek yemek yemeye sığındıkları ileri sürülmektedir.

Yukarıda açıklanan bilgilerden hareketle beklenmedik ve olağandışı durumların insanların stres düzeylerini arttırdığı bunun sonucunda da onların beslenme alışkanlıklarında bazı değişimlerin olabileceği varsayılmaktadır. Bu verilerden hareketle bu çalışma kapsamında tüketicilerin COVID-19 öncesi ve COVID-19 sonrası beslenme alışkanlıklarındaki değişimin nasıl olduğu ve bu olası değişimin onların demografik özelliklerine göre farklılaşıp farklılaşmadiğı incelenmiştir.

\section{Yöntem}

Nicel bir çalışma olan araştırmanın evrenini Türkiye'de yaşayan tüketiciler oluşturmaktadır ve bu bağlamda örneklem büyüklüğü 384 ve üzeri kişi ola- 
rak belirlenmiştir. Araştırmada örneklem yöntemi olarak tesadüfî örneklem yöntemi ve veri toplama aracı olarak çevrimiçi anket kullanılmıştır. Anket iki aşamadan oluşmakta olup ilk aşamada katılımcıların beslenme alışkanlıklarına yönelik literatürde daha önce kullanılmış anketlerden uyarlanmış 16 soru sorulmuştur. Katılımciların bu 16 soruyu yanitlarken COVID-19 öncesi ve COVID-19 sonrası durumu dikkate alarak yanıtlamaları istenmiştir. Anketin devamında ise katılımcların demografik özelliklerine yönelik 4 soru yer almaktadır. Katılımcilar anketleri 03-06 Nisan 2020 tarihleri arasında internetten çevrimiçi olarak doldurmuşlardır.

Çalışma kapsamında toplam 1258 kişiye ulaşılmış, anketler bilgisayar ortamına aktarılarak analizler bu veriler üzerinden gerçekleştirilmiştir. Ölçeğin güvenirliğini kontrol etmek için Cronbach Alpha testi uygulanmıştır. Katılımcıların demografik özellikleri ile beslenme alışkanlıklarındaki değişimin belirlenmesine yönelik frekans ve yüzde analizinden yararlanılmıştır. Katılımcıların beslenme alışkanlıklarının demografik özelliklerine göre farklılaşıp farklılaşmadığını belirlemek amacı ile ise bağımsız örneklem $t$ testi ve tek yönlü varyans analizi (ANOVA) uygulanmıştır.

\section{Bulgular ve tartışma}

Verilere uygulanan güvenirlik testi sonucunda ölçeğin Cronbach Alpha katsayısının. 670 olduğu gözlenmiş ve bu değere göre ölçeğin güvenirlik koşullarını sağladığını kabul edilmiştir. Katılımcıların demografik özelliklerinin frekans dağılımları incelendiğinde büyük çoğunluğu (\%78,7) 18-50 yaş aralığında yer aldığı, cinsiyet dağılımları birbirine yakın olmakla birlikte eğitim düzeyi bakımından yine büyük çoğunluğunun $(\% 70,1)$ üniversite mezunu olduğu görülmüştür. Katılımcların gelir durumuna göre dağılımına bakıldığında ise büyük çoğunluğun (\%66,1) 3001 TL ve üzeri gelire sahip olanlardan oluştuğu görülmüştür.

Tablo 2 katılımcıların COVID-19 öncesi ve COVID-19 sonrası beslenme alışkanlığındaki en büyük değişimin \%40 ile eve paket yemek siparişinde yaşandığı görülmüştür. Eve paket yemek siparişi vermeme oranı COVID-19 öncesinde \%43,5 iken COVID-19 sonrasında bu oran \%83,5'e çıkmıştır. Sıralamadaki en büyük ikinci değişim ise fast food tüketim alışkanlığıyla ilgili olandır. Sonuçlara göre COVID-19 öncesinde fast food tüketmeyenlerin oranı \%39,0 iken COVID-19 sonrasında bu oran \%76,9'a çıkmıştır. Fast food oranındaki değişimi sırayla market veya fırından ekmek alma ve bağışıklık sistemini güçlendirici gıdalar tüketme maddeleri izlemektedir. Bu iki maddeyle ilgili değişimler incelendiğinde; market veya firından ekmek alma yerine evde ekmek yapma oranının COVID-19 öncesinde \%5,7 iken COVID-19 sonrasinda bu oranın $\% 26,8$ çıktığı görülmektedir. Bir diğer madde olan bağışıklık sistemini güçlendirici gıdalar tüketmede her gün tüketiyorum seçeneği COVID-19 öncesinde \%38,3 iken COVID-19 sonrasında bu oran \%51,5'e yükselmiştir. 
Katılımcıların beslenme alışkanlıklarındaki değişimin cinsiyete göre farklılaşıp farklılaşmadığına yönelik yapılan analizde anlamlı bir farklılığın olduğu, söz konusu farklılıkta kadınların ortalamasının erkeklere nazaran daha yüksek olduğu gözlenmiştir. Öte yandan katılımcıların yaşlarına göre farklılaşmanın olup olmadığı yine anlamlı bir farklılığın olduğu söz konusu farklılı̆̆ın ise 18-35 yaş arası ile 36-50 yaş arasında gerçekleştiği görülmüştür. Son olarak katılımcıların gelir durumuna göre farklılaşma olup olmadığına yönelik yapılan analizde ise geliri olmayanlar ile 5000 TL ve üzeri geliri olanlara arasında anlamlı bir farklılık olduğu görülmüsstür.

\section{Sonuç ve öneriler}

Yukarıda analiz ve bulgular başlığı altında görüldüğü üzere COVID-19 sebebiyle ortaya çıkan olağanüstü ve beklenmedik durumlar sonucunda tüketicilerin beslenme alışkanlığında önemli oranda değişimler meydana gelmiştir. Bu değişimler arasında en yükseği \%40 ile eve paket yemek siparişi verme davranışında yaşanmaktadır. Bu değişim katılımcıların COVID-19 sebebiyle oluşturdukları hijyen duyarlılığından kaynaklanabileceği gibi, COVID-19'a yönelik alınan önlemler kapsamında yiyecek içecek işletmelerinin faaliyetlerinin kısıtlanmasından da kaynaklanabilir. Bu süreçte tüketicilere daha çok hijyen ve temizlik kurallarına uyduğuna inandıkları işletmelerden sipariş vermeleri ve sipariş teslim alma, ödeme yapma sürecinde mutlaka korunma tedbirlerini katı bir şekilde uygulamaları önerilebilir. Ayrıca paket servisi yapan işletmelerinde içinde bulunduğumuz olağanüstü koşullarda her türlü temizlik ve hijyen kurallarını katı bir şekilde uygulamaları tavsiye edilmektedir.

Yine aynı başlık altında görüleceği üzere sıralamadaki en büyük ikinci değişim fast food tüketim alışkanlığıyla ilgi olandır. Sonuçlara göre COVID-19 öncesinde fast food tüketmeyenlerin oranı \%39,0 iken COVID-19 sonrasinda bu oran \%76,9'a çıkmıştır. Bunun en önemli sebebi yine COVID-19 sebebiyle katılımcılarda ortaya çıkan sağlıklı beslenme eğiliminden kaynaklı olabilir. Tüketicilerin söz konusu bu olumlu durumu COVID-19 sonrası devam ettireceği varsayımından hareketle yiyecek içecek işletmelerinin ürünlerinde sağlıklı gıda türlerini daha ön plana çıkarmaları ve dengeli beslenme konusundaki hassasiyetlerini tüketicilerin dikkatine sunmaları tavsiye edilebilir. Beslenme alışkanlığındaki değişim sıralamasında üçüncü en büyük değişim \%21,1 ile evde ekmek yapma alışkanlığında gerçekleşmiştir. Market veya fırından ekmek alma yerine evde ekmek yapma oranının COVID-19 öncesinde \%5,7 iken COVID-19 sonrasında bu oranın \%26,8 çıktığı görülmektedir. Bu süreçte tüketicilere hijyen temizlik kuralları yanında emniyet kurallarına da özen göstermeleri önerilmektedir.

Analiz ve bulgular başlığı altında katılımcıların beslenme alışkanlıklarındaki değişimin cinsiyete göre, yaşa göre ve gelir durumuna göre farklılaştığı ileri 
sürülmektedir. Bu anlamda yiyecek içecek işletmelerinin özellikle kadın tüketicilerin bu hassasiyetini dikkate alan davranışlarını ön plana çıkarmaları, tüketicilere ise olumlu yönde değişen bu davranışlarını olağan şartlarda da sürdürmeleri önerilebilir. Çalışma içinde bulunulan olağanüstü şartlar sürecinde yapıldığından araştırmacılara benzer çalışmaları olağan şartlara geçildiğinde de yaparak sonuçları karşılaştırmaları önerilebilir. Yine araştırmacılara söz konusu çalışmalarını yurt dışındaki çalışmalarla karşılaştırarak benzerlik ve farklılıkları değerlendirmeleri önerilebilir. 


\section{Introduction}

As it is known, COVID-19 is a new and dangerous type of virus that started in December 2019 first in China and started to spread rapidly and uncontrollably to the whole world as of January 2020. COVID-19 is a family of viruses that cause colds, MERS and SARS diseases. This virus, called COVID-19 in the literature, is zoonotic (Acar, 2020; Akpınar and Üstün, 2020). It is reported that among the diseases caused by these viruses that lead to diseases in humans, SARS passed from bats to people in China in 2002 and MERS from camels to people in Saudi Arabia in 2012. It is stated that the first source of COVID-19, which emerged in December 2019, is a seafood market in Wuhan but contamination occurs from person to person through droplet or contact (Acar, 2020; Oval1, 2020).

Countries have a hard time stopping the spread of COVID-19, which is accepted as a pandemic (global) by the World Health Organization (WHO). In order to prevent the spread, Turkey, like in many countries worldwide, has taken some radical measures and is continuing to do so. Curfew, quarantine of the places where the virus is common, temporary closure of many workplaces, social isolation, non-contact with any object and / or people and social distance are the most important ones (Ministry of Interior [MOI], 2020).

As a result of these measures, which have been implemented in our country as in many other countries in the world, the majority of people have had to stay home. In this process, it is inevitable for many people to have changes in their economic, social and psychological states. One of these changes is thought to be related to dietary habits. This is because people spend most of their time outside for the purpose of work, education and social activity, and their nutritional habits were also shaped in line with these usual lifestyles. However, due to the extraordinary situation we are in, people have to spend their time in their homes now. In addition, shopping malls were closed for precautionary purposes, food and beverage businesses were allowed to provide only takeaway service and working hours of the supermarkets were restricted. It is assumed that this unexpected situation and uncertainty will increase their anxiety and stress levels, because it is argued that uncertainty the results of which are not fully predicted increases the level of stress (Atkinson et al., 1999).

It is asserted that there are multiple factors that affect people's nutritional habits (Shepherd and Dennison, 1996). Different classifications are made for these factors. These are classified not only as factors associated with the product, consumer and environment but also as biological, psychological, cultural and social factors (Babicz-Zielinska et al., 2006; Vabo and Hansen, 2014). It is argued that the psychological factor is more effective than the biological, psychological, cultural and social factors which affect the nutritional habits (Babicz-Zielinska et al., 2006). 
In the studies on the effects of stress, it is reported that stress is closely related to the nutritional habit as it occurs when the physical and psychological limits of the organism are strained and threatened (Baltaş and Baltaş, 2000; Davison and Neal, 2005). It is asserted that when an abnormal situation that threatens the individual is detected, the human body is immediately alarmed and can give psychological, physiological, behavioural and emotional reactions, and one of those is associated with nutrition (Culbert et al., 2015). It is claimed that these reactions are related to how individuals understand and interpret the events, and some individuals react more and others do less despite the same conditions (Yöndem, 2006).

A number of studies conducted on the subject suggest that the human body has a deep interest in certain types of food as a result of the search for self-recovery during stress periods (Rozin et al., 1991; Stein, 2008). It is argued that these foods are mostly high-calorie and sugary foods and this is related to the production of serotonin in the body (Wansink et al., 2003). For this reason, it is claimed that some individuals prefer to eat a lot by choosing psychological comfort instead of physiological comfort when under stress (Kandiah et al., 2006).

Based on the studies above, it is assumed that unexpected and unusual situations increase the stress levels of people, and as a result, there could be some changes in their nutritional habits. Considering this data, how the changes in the nutritional habits of consumers before COVID-19 and after COVID-19 differ, and whether this possible change differs according to their demographic characteristics will be examined within the scope of this study. Thus, possible nutritional habits of consumers after COVID-19 will be determined. In line with these habits, it will be possible to make scientific recommendations to the food and beverage businesses related to their plans to increase consumer satisfaction and customer loyalty after COVID-19.

\section{Literature review}

The details concerning some research on nutritional habits and nutritional behaviours under stress are listed below chronologically.

A study was conducted by Şen (2020) to specify the extent to which the foodservice companies were affected by the epidemic of COVID-19, and the precautions that were taken, if any. In the research, it was determined that the employees who were working in the process of COVID-19 and consumed their food at the workplace wanted the products such as water, yoghurt, bread, and salad to be packaged for individual use and the equipment such as forks, spoons and knives that they used to be disposable because of the concern of being infected.

According to a study which was carried out in Marmara University to analyse the nutritional mores and physical mobility levels of academics and included 
225 participants, $72 \%$ of the participants always skipped meals while $22.7 \%$ of them sometimes skipped meals. Only $5.3 \%$ of the participants consumed three meals a day without skipping any meals. When the weight these participants were measured, $4.9 \%$ were regarded as thin, $58.6 \%$ as normal weight, $29.8 \%$ as overweight and 6.7\% as extremely fat (obese) (Arslan, 2018).

Penaforte, Matta and Japur (2016) carried out a research in two stages to search the relation among stress, nutritional behaviour and food intake. In the first stage, stress and eating behaviour measurements perceived by the participants were made. In the second stage, the three-day eating records of the participants were kept. As a result of the investigation, it was determined that the group with higher stress level consumes instant foods like fast food and sugary foods more. On the other hand, it was detected that participants with higher stress levels had more emotional and uncontrolled eating habits.

In the study by Onurlubaş and Çakırlar (2016) to determine the factors affecting the consumers' milk and dairy consumption, it was determined that there were four factors which are confidence, price, nutritional value and expire date. It was also found that there were no important veriation between the gender of the attenders and their judgments regarding the dimensions of confidence, price, nutritional value and expire date.

Tryon, DeCant and Laugero (2013) performed an experiment to measure the relationship between chronic social stress and food consumption. Different measurements were made that measured the physical activity, sleep status, blood chemistry and eating behaviours of the participants. The attenders in the experimental group were subjected to the social stress test and the participants in the control group watched a nature video accompanied with classical music. After the stress and control tests, the participants were offered a buffet consisting of low-fat snacks, spicy-fat snacks, and sweet snacks. Consequently the research, it was concluded that the body mass index of the attenders reporting high chronic stress were high and that they consumed a considerable amount of chocolate cake.

A study conducted by Unur and Gök (2012) on the reasons for eating fast food revealed that $29.3 \%$ of the participants consumed fast food 3-4 times a week, $14.5 \%$ of them 5-6 times per week, and 15\% of them 7 times per week or more. As for that outcome of the study, it was specified that the customers consumed convenience foods because they got hungry when they were outside, they loved the flavour, they could easily access it, and they got hungry while shopping (Unur and Gök, 2012).

According to a study conducted on 96 students studying at Süleyman Demirel University, it was determined that $79.8 \%$ of the participants ate their meals where they lived, and the remaining $20.2 \%$ ate out. fruit and vegetable 
consumption habits were asked to The same students, and it was found that $13.8 \%$ of them consumed fruit or vegetable once or twice a month, $59.6 \%$ once or twice per week, and $26.6 \%$ every day. In addition, it was reported that a total of $14.9 \%$ of the students attendance in the study did not consume any milk, $19.1 \%$ consumed milk at least once a day, 35.1\% drank milk once a week, and $30.9 \%$ consumed milk once a month (Saygin et al., 2011).

A study was conducted by Çetinkaya (2010) in order to determine the habits of milk and dairy products depletion among the students in different departments at Kafkas University. The results indicated that $76 \%$ of the students preferred dairy products instead of milk itself. It was also found out that $46.9 \%$ of the students consumed cheese, $32 \%$ ate yogurt, $15.6 \%$ consumed butter, $1.5 \%$ ate powdered milk, and $2 \%$ consumed milk with fruit and yogurt with fruit. According to the research findings, it was determined that the generality of the students didn't have a ordinate milk consumption habit, and the consumption of cheese and yoghurt out of milk products was a priority for them and they had very limited knowledge about drinking milk.

A study by Born et al. (2009) aimed to specify the impact of acute stress on food choice and food choice reward-related brain activity. In the study, it was concluded that stress reduced activation in many reward-related regions of the brain, and increased the tendency towards foods with higher carbohydrate and protein content.

A study was applied to reveal the nutritional knowledge, nutritional habits and nutritional problems of the students studying Marmara University Faculty of Medicine. In the study, in which 264 students participated, it was determined that $69.7 \%$ of the students had a moderate level of total general nutrition knowledge, that $30.7 \%$ also had a moderate level of total medical nutrition knowledge, and that $55.3 \%$ of the participants had moderate total nutritional behaviour knowledge, too. In the study, it was found that $59.1 \%$ of the students skipped meals and the most skipped one was breakfast. In addition, the total general nutrition information scores and the medical nutrition information scores of the females were specfied to be dramatically higher than the males (Astarl1, 2008).

The two-stage study conducted by Zellner et al. (2006) investigated the effect of stress on food choice. The first stage of the study experimentally demonstrated that stress caused a shift from healthy and low-fat foods to less healthy and highfat foods in food choice. In the second stage of the study, it was revealed that women increased their food consumption more than men when stressed. Both studies indicate that stress not only enhanced consumption in certain individuals, but also changed their food choice from low-fat foods to higher-fat ones.

Paeratekul, Ferdinand, Champagne, Ryan and Bray (2003) conducted a study to determine the fast food consumption, and dietary and nutrient intake profile 
of American adults and children. In the study, it was concluded that those with a higher education level consumed more fast food than others.

In the light of the studies in the literature, the main research question of the study was formed as follows:

RQ1: Has there been a change in consumers' nutritional habits due to COVID-19?

The second research question created based on the result of this basic research question is as follows:

RQ2: Does the possible change in the nutritional habits differ based on the demographic characteristics of the participants (age, gender, educational background and income)?

\section{Method}

The main purpose of this study is to find out whether there is a change in the nutritional habits of consumers in the unexpected and unusual period caused by coronavirus (COVID-19). Another aim of the study is to determine whether these changing dietary habits differ according to the demographic characteristics of the participants (age, gender, educational background, etc.). The research population consisted of the consumers living in Turkey and in this context; the sample size was determined to be 384 or more people (Altunış1k et al., 2007).

Simple random sampling method, one of the probabilistic sampling methods, was used as the sampling method in the study, and an online questionnaire was employed as the data collection tool. The questionnaire consisted of two parts. The first part of the questionnaire included 16 questions about the nutritional habits of the participants. These 16 questions were adapted from the questionnaires used previously in the literature (Kahraman, 2018). Participants were asked to answer these questions taking into consideration the situation before COVID-19 and after COVID-19. The second part of the questionnaire comprised four questions regarding the demographic characteristics of the participants. The participants filled the questionnaires online on 18-22 May, 2020.

Within the scope of the study, a total of 1258 people were reached, the questionnaires were transferred to the computer environment, and the analyses were performed on these data. Before the analysis, the normality control of the research data was examined with the Q-Q graph test and the control of the skewness and kurtosis values (Çokluk, Şekercioğlu and Büyüköztürk, 2010:15). According to the analysis made, it was concluded that the data were distributed normally. Cronbach's Alpha test was applied to check the reliability of the scale (Ural and Kılıç, 2005: 258). Frequency and percentage analyses were used to 
determine the demographic characteristics of the participants and the change in their nutritional habits. Independent samples t-test and one-way analysis of variance (ANOVA) were conducted to determine whether the nutritional habits of the participants differed based on their demographic characteristics (Büyüköztürk, 2010: 91).

In conducting this study, it has been decided that there is no ethical problem along with Giresun University Scientific Research and Publication Ethics Committee's decision dated 11 May 2020, meeting 44079388-38 and decision 2020-2.

\section{Analysis and findings}

As stated in the method section, the data obtained from 1258 questionnaires, which were filled online on 18-22 May 2020, were transferred to the computer environment and the analyses were performed on these data. As a result of the reliability test applied to the data, the Cronbach's Alpha coefficient of the scale was found to be .670 . Considering this value, it can be stated that the scale meets the reliability requirements (Büyüköztürk, 2010: 168).

Table 1: The frequency distribution of the demographic characteristics of the participants

\begin{tabular}{lcc}
\hline \multicolumn{1}{c}{ Age } & Distribution & Percentage (\%) \\
\hline \multicolumn{1}{c}{ 18-35 years } & 476 & 37,8 \\
36-50 years & 515 & 40,9 \\
51 years and above & 267 & 21,2 \\
Total & 1258 & 100 \\
\hline \multicolumn{1}{c}{ Gender } & & \\
Female & 632 & 50,2 \\
Male & 626 & 49,8 \\
Total & 1258 & 100 \\
$\quad$ Educational Background & & \\
Primary School & 105 & 8,3 \\
High School & 271 & 21,5 \\
University & 882 & 70,1 \\
Total & 1258 & 100 \\
\hline \multicolumn{1}{c}{ Income } & & \\
No income & 139 & 11,0 \\
Below 3000 TL & 288 & 22,9 \\
Between 3001-5000 TL & 406 & 32,3 \\
Above 5000 TL & 425 & 33,8 \\
Total & 1258 & 100 \\
\hline
\end{tabular}


Table 1 demonstrates the frequency distributions of the demographic characteristics of the participants. As can be seen, the vast majority of the participants $(78.7 \%)$ were aged between $18-50$ years. While the gender distributions of the participants were close to each other, the majority $(70.1 \%)$ were university graduates. When the income distribution of the participants is analyzed, it is observed that the majority $(66.1 \%)$ had an income of $3001 \mathrm{TL}$ and above.

Table 2: The changes in the nutritional habits of the participants before and after COVID-19

\begin{tabular}{|c|c|c|c|c|c|c|}
\hline \multirow[b]{2}{*}{ Survey question } & \multirow[b]{2}{*}{ Option } & \multicolumn{2}{|c|}{$\begin{array}{c}\text { Before } \\
\text { COVID-19 }\end{array}$} & \multicolumn{2}{|c|}{$\begin{array}{c}\text { After } \\
\text { COVID-19 }\end{array}$} & \multirow[b]{2}{*}{$\begin{array}{c}\text { Difference } \\
\%\end{array}$} \\
\hline & & Frequency & $\%$ & Frequency & $\%$ & \\
\hline \multirow{4}{*}{$\begin{array}{l}\text { 1) Do you order } \\
\text { takeaway food } \\
\text { (pizza, lahmacun, } \\
\text { doner kebab)? }\end{array}$} & Once a week & 158 & 12,6 & 50 & 4 & $-8,6$ \\
\hline & Once a month & 553 & 44 & 157 & 12,5 & $-31,5$ \\
\hline & Never & 547 & 43,5 & 1051 & 83,5 & 40 \\
\hline & Total & 1258 & 100 & 1258 & 100 & 0 \\
\hline \multirow{4}{*}{$\begin{array}{l}\text { 2) How often do } \\
\text { you eat fast food? }\end{array}$} & Once a week & 276 & 21,9 & 101 & 8,1 & $-13,8$ \\
\hline & Once a month & 492 & 39,1 & 189 & 15 & $-24,1$ \\
\hline & Never & 490 & 39 & 968 & 76,9 & 37,9 \\
\hline & Total & 1258 & 100 & 1258 & 100 & 0 \\
\hline \multirow{3}{*}{$\begin{array}{l}\text { 3) Do you buy bread } \\
\text { from the grocery } \\
\text { or bakery? }\end{array}$} & I do & 1186 & 94,3 & 921 & 73,2 & $-21,1$ \\
\hline & $\begin{array}{l}\text { I bake it at } \\
\text { home }\end{array}$ & 72 & 5,7 & 337 & 26,8 & 21,1 \\
\hline & Total & 1258 & 100 & 1258 & 100 & 0 \\
\hline \multirow{5}{*}{$\begin{array}{l}\text { 4) Do you consume } \\
\text { immune-boosting } \\
\text { foods (yogurt, } \\
\text { kefir, sources of } \\
\text { vitamin c)? }\end{array}$} & Every day & 482 & 38,3 & 648 & 51,5 & 13,2 \\
\hline & $\begin{array}{l}\text { More than } \\
\text { once a week }\end{array}$ & 418 & 33,2 & 370 & 29,4 & $-3,8$ \\
\hline & Once a week & 244 & 19,4 & 149 & 11,8 & $-7,6$ \\
\hline & Once a month & 114 & 9,1 & 91 & 7,2 & $-1,9$ \\
\hline & Total & 1258 & 100 & 1258 & 100 & 0 \\
\hline \multirow{5}{*}{$\begin{array}{l}\text { 5) Why do you skip } \\
\text { meals? }\end{array}$} & I don't feel like & 458 & 36,4 & 545 & 43,3 & 6,9 \\
\hline & $\begin{array}{l}\text { I don't have } \\
\text { time }\end{array}$ & 363 & 28,9 & 198 & 15,7 & $-13,2$ \\
\hline & $\begin{array}{l}\text { I want to lose } \\
\text { weight }\end{array}$ & 149 & 11,8 & 158 & 12,6 & 0,8 \\
\hline & $\begin{array}{l}\text { I find it } \\
\text { unnecessary }\end{array}$ & 288 & 22,9 & 357 & 28,4 & 5,5 \\
\hline & Total & 1258 & 100 & 1258 & 100 & 0 \\
\hline
\end{tabular}


Table 2 (More): The changes in the nutritional habits of the participants before and after COVID-19

\begin{tabular}{|c|c|c|c|c|c|c|}
\hline \multirow[b]{2}{*}{ Survey question } & \multirow[b]{2}{*}{ Option } & \multicolumn{2}{|c|}{$\begin{array}{c}\text { Before } \\
\text { COVID-19 }\end{array}$} & \multicolumn{2}{|c|}{$\begin{array}{c}\text { After } \\
\text { COVID-19 }\end{array}$} & \multirow[b]{2}{*}{$\begin{array}{c}\text { Difference } \\
\% \\
\end{array}$} \\
\hline & & Frequency & $\%$ & Frequency & $\%$ & \\
\hline \multirow{3}{*}{$\begin{array}{l}\text { 6) Do you think you } \\
\text { have a balanced } \\
\text { diet? }\end{array}$} & Yes & 754 & 59,9 & 905 & 71,9 & 12 \\
\hline & No & 504 & 40,1 & 353 & 28,1 & -12 \\
\hline & Total & 1258 & 100 & 1258 & 100 & 0 \\
\hline \multirow{4}{*}{$\begin{array}{l}\text { 7) How many meals } \\
\text { do you eat a day? }\end{array}$} & 2 meals & 446 & 35,5 & 570 & 45,3 & 9,8 \\
\hline & 3 meals & 732 & 58,2 & 649 & 51,6 & $-6,6$ \\
\hline & 4 and above & 80 & 6,4 & 39 & 3,1 & $-3,3$ \\
\hline & Total & 1258 & 100 & 1258 & 100 & 0 \\
\hline \multirow{5}{*}{$\begin{array}{l}\text { 8) If you skip any } \\
\text { meals in a day, } \\
\text { which one do you } \\
\text { skip most? }\end{array}$} & Breakfast & 308 & 24,5 & 191 & 15,2 & $-9,3$ \\
\hline & Lunch & 590 & 46,9 & 615 & 48,9 & 2 \\
\hline & Dinner & 89 & 7,1 & 68 & 5,4 & $-1,7$ \\
\hline & $\begin{array}{l}\text { I don't skip } \\
\text { any }\end{array}$ & 271 & 21,5 & 384 & 30,5 & 9 \\
\hline & Total & 1258 & 100 & 1258 & 100 & 0 \\
\hline \multirow{3}{*}{$\begin{array}{l}\text { 9) Where do you } \\
\text { usually prefer } \\
\text { eating? }\end{array}$} & At home & 1126 & 89,5 & 1241 & 98,5 & 9 \\
\hline & Outside & 132 & 10,5 & 17 & 1,5 & -9 \\
\hline & Total & 1258 & 100 & 1258 & 100 & 0 \\
\hline \multirow{5}{*}{$\begin{array}{l}\text { 10) Do you consume } \\
\text { any fruit and/or } \\
\text { vegetables? }\end{array}$} & Every day & 612 & 48,6 & 725 & 57,6 & 9 \\
\hline & $\begin{array}{l}\text { More than } \\
\text { once a week }\end{array}$ & 412 & 32,8 & 372 & 29,6 & $-3,2$ \\
\hline & Once a week & 191 & 15,2 & 119 & 9,5 & $-5,7$ \\
\hline & Once a month & 43 & 3,4 & 42 & 3,3 & $-0,1$ \\
\hline & Total & 1258 & 100 & 1258 & 100 & 0 \\
\hline \multirow{4}{*}{$\begin{array}{l}\text { 11) How many litres } \\
\text { of water do you } \\
\text { consume a day? }\end{array}$} & $\begin{array}{l}\text { Less than } 1 \\
\text { litre }\end{array}$ & 375 & 29,8 & 265 & 21,1 & $-8,7$ \\
\hline & $\begin{array}{l}\text { Between 1-2 } \\
\text { litres }\end{array}$ & 637 & 50,6 & 696 & 55,3 & 4,7 \\
\hline & $\begin{array}{l}\text { More than } 2 \\
\text { litres }\end{array}$ & 246 & 19,6 & 297 & 23,6 & 4 \\
\hline & Total & 1258 & 100 & 1258 & 100 & 0 \\
\hline \multirow{3}{*}{$\begin{array}{l}\text { 12) Do you pay } \\
\text { attention to } \\
\text { washing hands } \\
\text { before and after } \\
\text { meals? }\end{array}$} & Yes & 1144 & 90,9 & 1239 & 98,5 & 7,7 \\
\hline & No & 114 & 9,1 & 19 & 1,5 & $-7,7$ \\
\hline & Total & 1258 & 100 & 1258 & 100 & 0 \\
\hline
\end{tabular}


Table 2 (More): The changes in the nutritional habits of the participants before and after COVID-19

\begin{tabular}{|c|c|c|c|c|c|c|}
\hline \multirow[b]{2}{*}{ Survey question } & \multirow[b]{2}{*}{ Option } & \multicolumn{2}{|c|}{$\begin{array}{c}\text { Before } \\
\text { COVID-19 }\end{array}$} & \multicolumn{2}{|c|}{$\begin{array}{c}\text { After } \\
\text { COVID-19 }\end{array}$} & \multirow[b]{2}{*}{$\begin{array}{c}\text { Difference } \\
\% \\
\end{array}$} \\
\hline & & Frequency & $\%$ & Frequency & $\%$ & \\
\hline \multirow{3}{*}{$\begin{array}{l}\text { 13) Do you consume } \\
\text { alcohol? }\end{array}$} & Yes & 193 & 15,3 & 127 & 10,1 & $-5,2$ \\
\hline & No & 1065 & 84,7 & 1131 & 89,9 & 5,2 \\
\hline & Total & 1258 & 100 & 1258 & 100 & 0 \\
\hline \multirow{3}{*}{ 14) Do you smoke? } & Yes & 373 & 29,7 & 328 & 26,1 & $-3,6$ \\
\hline & No & 885 & 70,3 & 930 & 73,9 & 3,6 \\
\hline & Total & 1258 & 100 & 1258 & 100 & 0 \\
\hline \multirow{4}{*}{$\begin{array}{l}\text { 15) Are you satisfied } \\
\text { with your } \\
\text { weight? }\end{array}$} & Yes & 441 & 35,1 & 431 & 34,3 & $-0,8$ \\
\hline & Partially & 446 & 35,5 & 421 & 33,5 & -2 \\
\hline & No & 371 & 29,5 & 406 & 32,3 & 2,8 \\
\hline & Total & 1258 & 100 & 1258 & 100 & 0 \\
\hline \multirow{4}{*}{$\begin{array}{l}\text { 16) Are you aware } \\
\text { of obesity? }\end{array}$} & Yes & 1123 & 89,3 & 1120 & 89 & $-0,3$ \\
\hline & I have no idea & 61 & 4,8 & 71 & 5,6 & 0,9 \\
\hline & No & 74 & 5,9 & 67 & 5,3 & $-0,6$ \\
\hline & Total & 1258 & 100 & 1258 & 100 & 0 \\
\hline
\end{tabular}

Table 2 presents information about the nutritional habits of the participants before COVID-19 and after COVID-19. The last column of the table shows whether the nutritional habits have changed, if it has changed, it gives the rate of the change as a percentage (\%). In order to analyze the results better, the change in the nutritional habits are listed in a descending order. According to the ranking, the biggest change was seen in ordering takeaway food with $40 \%$. While the rate of not ordering takeaway food was $43.5 \%$ before COVID- 19 , this rate climbed to $83.5 \%$ after COVID-19.

The second biggest change in the ranking is the one concerning the fast food consumption habit. According to the results, while the rate of those who did not consume fast food before COVID-19 was 39.0\%, this rate increased to $76.9 \%$ after COVID-19. The change in fast food consumption rate was followed by buying bread from the grocery or bakery and consuming immune-boosting foods. When the changes related to these two items are examined, it is observed that the rate of making bread at home instead of buying it from the grocery or bakery was 5.7\% before COVID-19 whereas it was 26.8\% after COVID-19. With respect to consuming immune-boosting foods, the response option "every day" was rated by $38.3 \%$ of the participants before COVID-19 while this rate increased to $51.5 \%$ after COVID-19. 
According to the analyses, the last two questions with a change of more than $10 \%$ are "Why do you skip meals?" and "Do you think you have a balanced diet?". It can be seen that the response rate of one of the options given to the question "Why do you skip meals?" decreased after COVID-19. This decrease was observed in the response option "I don't have time" and the rate which was $28.9 \%$ before COVID-19 decreased to $15.7 \%$ after COVID-19. In addition, there was an increase in the number of the participants who believed that they had a balanced diet after COVID-19 as there was in the first four questions. While the rate was 59.9\% before COVID-19, it rose to $71.9 \%$ after COVID-19.

Table 3: T table showing the differences in the nutritional habits of the participants according to gender

\begin{tabular}{|c|c|c|c|c|c|c|c|}
\hline Survey question & Gender & $\mathbf{N}$ & Mean & $\begin{array}{c}\text { S. } \\
\text { Deviation } \\
\end{array}$ & $\mathbf{t}$ & df & $\mathrm{p}$ \\
\hline \multirow{2}{*}{$\begin{array}{l}\text { 1) Do you order takeaway food } \\
\text { (pizza, lahmacun, doner } \\
\text { kebab)? }\end{array}$} & emale & 632 & 3,8323 & 0,432 & \multirow{2}{*}{2,654} & \multirow{2}{*}{1191} & \multirow{2}{*}{ D } \\
\hline & Male & 626 & 3,7588 & 0,543 & & & \\
\hline \multirow{2}{*}{$\begin{array}{l}\text { 2) How often do you eat fast } \\
\text { food? }\end{array}$} & Female & 632 & 3,7152 & 0,588 & \multirow{2}{*}{1,514} & \multirow{2}{*}{1247} & \multirow{2}{*}{0,006} \\
\hline & Male & 626 & 3,6629 & 0,634 & & & \\
\hline \multirow{2}{*}{$\begin{array}{l}\text { 3) Do you buy bread from the } \\
\text { grocery or bakery? }\end{array}$} & Female & 632 & 1,3038 & 0,4 & \multirow{2}{*}{2,897} & \multirow{2}{*}{1248} & \multirow{2}{*}{0} \\
\hline & Male & 626 & 1,2316 & 0,422 & & & \\
\hline \multirow{2}{*}{$\begin{array}{l}\text { 4) Do you consume immune- } \\
\text { boosting foods (yogurt, } \\
\text { kefir, sources of vitamin c)? }\end{array}$} & Female & 632 & 1,6187 & 0,884 & \multirow{2}{*}{$-5,018$} & \multirow{2}{*}{1247} & \multirow{2}{*}{0,663} \\
\hline & Male & 626 & 1,8786 & 0,952 & & & \\
\hline \multirow{2}{*}{ 5) Why do you skip meals? } & Fem & 632 & 2,2041 & 1,282 & \multirow{2}{*}{$-1,56$} & \multirow{2}{*}{1255} & \multirow{2}{*}{0,592} \\
\hline & Male & 626 & 2,3163 & 1,267 & & & \\
\hline \multirow{2}{*}{$\begin{array}{l}\text { 6) Do you think you have a } \\
\text { balanced diet? }\end{array}$} & Female & 632 & 1,5791 & 0,907 & \multirow{2}{*}{0,71} & \multirow{2}{*}{1255} & \multirow{2}{*}{0,156} \\
\hline & Male & 626 & 1,5431 & 0,89 & & & \\
\hline
\end{tabular}

Table 3 illustrates whether the changes in the nutritional habits of the participants differed according to gender. Questions which had a change higher than 10\% were included in the table so as not to take up a lot of space. The analysis of the table indicates that the first three questions where the highest change occurred differed according to gender whereas there was no significant difference in the other three questions based on gender. According to the results of the analysis, it is observed that the mean values of the females were higher than those of the males in all of the three differences. 
Table 4: ANOVA table revealing the differences in the nutritional habits of the participants according to age

\begin{tabular}{|c|c|c|c|c|c|c|c|}
\hline Survey question & Age & $\mathbf{N}$ & $\ddot{\mathbf{X}}$ & SD & F & Sig. & Difference \\
\hline \multirow{3}{*}{$\begin{array}{l}\text { 1) Do you order } \\
\text { takeaway food } \\
\text { (pizza, lahmacun, } \\
\text { doner kebab)? }\end{array}$} & 1)18-35 years* & 476 & 3,73 & 0,54 & \multirow{3}{*}{8,377} & \multirow{3}{*}{0} & \multirow{3}{*}{$1<2,3$} \\
\hline & 2)36-50 years * & 515 & 3,8 & 0,47 & & & \\
\hline & 3)50 years and above* & 267 & 3,88 & 0,4 & & & \\
\hline \multirow{3}{*}{$\begin{array}{l}\text { 2) How often do } \\
\text { you eat fast food? }\end{array}$} & 1)18-35 years * & 476 & 3,54 & 0,7 & \multirow{3}{*}{28,31} & \multirow{3}{*}{0} & \multirow{3}{*}{$1<2,3$} \\
\hline & 2)36-50 years * & 515 & 3,72 & 0,57 & & & \\
\hline & 3)50 years and above* & 267 & 3,88 & 0,39 & & & \\
\hline \multirow{3}{*}{$\begin{array}{l}\text { 3) Do you buy bread } \\
\text { from the grocery } \\
\text { or bakery? }\end{array}$} & 1)18-35 years & 476 & 1,28 & 0,45 & \multirow{3}{*}{1,318} & \multirow{3}{*}{0,268} & \multirow{3}{*}{-} \\
\hline & 2)36-50 years & 515 & 1,24 & 0,43 & & & \\
\hline & 3)50 years and above & 267 & 1,27 & 0,44 & & & \\
\hline \multirow{3}{*}{$\begin{array}{l}\text { 4) Do you consume } \\
\text { immune-boosting } \\
\text { foods (yogurt, } \\
\text { kefir, sources of } \\
\text { vitamin c)? }\end{array}$} & 1)18-35 years * & 476 & 1,79 & 0,95 & \multirow{3}{*}{4,636} & \multirow{3}{*}{0,01} & \multirow{3}{*}{$3<2,1$} \\
\hline & 2)36-50 years * & 515 & 1,78 & 0,93 & & & \\
\hline & 3) 50 years and above* & 267 & 1,59 & 0,86 & & & \\
\hline \multirow{3}{*}{$\begin{array}{l}\text { 5) Why do you skip } \\
\text { meals? }\end{array}$} & 1)18-35 years * & 476 & 2,14 & 1,22 & \multirow{3}{*}{3,112} & \multirow{3}{*}{0,045} & \multirow{3}{*}{$1<2$} \\
\hline & 2)36-50 years * & 515 & 2,34 & 1,29 & & & \\
\hline & 3)50 years and above & 267 & 2,29 & 1,32 & & & \\
\hline \multirow{3}{*}{$\begin{array}{l}\text { 6) Do you think you } \\
\text { have a balanced } \\
\text { diet? }\end{array}$} & 1)18-35 years * & 476 & 1,73 & 0,96 & \multirow{3}{*}{18,84} & \multirow{3}{*}{0} & \multirow{3}{*}{$1>2,3$} \\
\hline & 2)36-50 years * & 515 & 1,52 & 0,87 & & & \\
\hline & 3)50 years and above* & 267 & 1,32 & 0,74 & & & \\
\hline
\end{tabular}

Table 4 shows whether there was a difference in the questions in which the highest change occurred according to the age of the participants. The table indicates that the change in five of the questions except for the question "Do you buy bread from the grocery or bakery?" also differed according to the age of the participants. When the mean differences were analyzed, it was observed that the age group of 18-35 had a higher mean in questions 1, 2 and 6, compared to other age groups. In addition, it is noteworthy that the participants aged between 18 and 35 had a higher mean in question 5 compared to those in the 36-50 age range. Moreover, in question 4, unlike the others, it is seen that the mean values of those who were 50 years old and above were higher than those of the other age groups. 
Table 5: ANOVA table revealing the differences in the nutritional habits of the participants according to income

\begin{tabular}{|c|c|c|c|c|c|c|c|}
\hline Survey question & Income & $\mathbf{N}$ & $\ddot{\mathbf{X}}$ & SD & $\mathbf{F}$ & Sig. & Difference \\
\hline \multirow{4}{*}{$\begin{array}{l}\text { 1) Do you order } \\
\text { takeaway food } \\
\text { (pizza, lahmacun, } \\
\text { doner kebab)? }\end{array}$} & 1)No income & 139 & 3,8 & 0,43 & \multirow{4}{*}{0,996} & \multirow{4}{*}{0,394} & \multirow{4}{*}{ - } \\
\hline & 2)Below $3000 \mathrm{TL}$ & 288 & 3,82 & 0,43 & & & \\
\hline & $\begin{array}{l}\text { 3)Between } \\
\text { 3001-5000 }\end{array}$ & 406 & 3,76 & 0,52 & & & \\
\hline & 4)Above $5000 \mathrm{TL}$ & 425 & 3,8 & 0,51 & & & \\
\hline \multirow{4}{*}{$\begin{array}{l}\text { 2) How often do you } \\
\text { eat fast food? }\end{array}$} & 1)No income* & 139 & 3,53 & 0,71 & \multirow{4}{*}{5,232} & \multirow{4}{*}{0,001} & \multirow{4}{*}{$1<4$} \\
\hline & 2) Below $3000 \mathrm{TL}$ & 288 & 3,68 & 0,62 & & & \\
\hline & $\begin{array}{l}\text { 3)Between } \\
\text { 3001-5000 }\end{array}$ & 406 & 3,67 & 0,61 & & & \\
\hline & 4)Above $5000 \mathrm{TL}^{*}$ & 425 & 3,76 & 0,54 & & & \\
\hline \multirow{4}{*}{$\begin{array}{l}\text { 3) Do you buy bread } \\
\text { from the grocery } \\
\text { or bakery? }\end{array}$} & 1)No income & 139 & 1,32 & 0,46 & \multirow{4}{*}{0,997} & \multirow{4}{*}{0,394} & \multirow{4}{*}{-} \\
\hline & 2) Below $3000 \mathrm{TL}$ & 288 & 1,24 & 0,43 & & & \\
\hline & $\begin{array}{l}\text { 3)Between } \\
\text { 3001-5000 }\end{array}$ & 406 & 1,26 & 0,43 & & & \\
\hline & 4)Above $5000 \mathrm{TL}$ & 425 & 1,27 & 0,44 & & & \\
\hline \multirow{4}{*}{$\begin{array}{l}\text { 4) Do you consume } \\
\text { immune-boosting } \\
\text { foods (yogurt, } \\
\text { kefir, sources of } \\
\text { vitamin c)? }\end{array}$} & 1)No income & 139 & 1,79 & 0,97 & \multirow{4}{*}{0,981} & \multirow{4}{*}{0,401} & \multirow{4}{*}{ - } \\
\hline & 2) Below $3000 \mathrm{TL}$ & 288 & 1,78 & 0,97 & & & \\
\hline & $\begin{array}{l}\text { 3)Between } \\
\text { 3001-5000 }\end{array}$ & 406 & 1,76 & 0,91 & & & \\
\hline & 4)Above $5000 \mathrm{TL}$ & 425 & 1,68 & 0,89 & & & \\
\hline \multirow{4}{*}{$\begin{array}{l}\text { 5) Why do you skip } \\
\text { meals? }\end{array}$} & 1)No income & 139 & 2,04 & 1,18 & \multirow{4}{*}{2,537} & \multirow{4}{*}{0,055} & \multirow{4}{*}{-} \\
\hline & 2)Below $3000 \mathrm{TL}$ & 288 & 2,17 & 1,25 & & & \\
\hline & $\begin{array}{l}\text { 3)Between } \\
\text { 3001-5000 }\end{array}$ & 406 & 2,32 & 1,27 & & & \\
\hline & 4)Above $5000 \mathrm{TL}$ & 425 & 2,33 & 1,31 & & & \\
\hline \multirow{4}{*}{$\begin{array}{l}\text { 6) Do you think you } \\
\text { have a balanced } \\
\text { diet? }\end{array}$} & 1)No income* & 139 & 1,87 & 0,99 & \multirow{4}{*}{10,14} & \multirow{4}{*}{0} & \multirow{4}{*}{$1>2,3,4$} \\
\hline & 2) Below $3000 \mathrm{TL}^{*}$ & 288 & 1,61 & 0,92 & & & \\
\hline & $\begin{array}{l}\text { 3)Between } \\
\text { 3001-5000* }\end{array}$ & 406 & 1,56 & 0,9 & & & \\
\hline & 4)Above $5000 \mathrm{TL}^{*}$ & 425 & 1,41 & 0,81 & & & \\
\hline
\end{tabular}

Table 5 presents whether the nutritional habits of the participants differed according to their income in the questions with the highest change. As it is understood from the table, the difference is only seen in the items related to the frequency of fast food consumption and having a balanced diet. When these items are analyzed, it is seen that the mean values of those who did not have any income were higher than those who had an income of 5000 TL and above 
in the first item, and in the second item, the mean values of those who did not have any income were higher than other groups.

Table 6: ANOVA table revealing the differences in the nutritional habits of the participants according to educational background

\begin{tabular}{|c|c|c|c|c|c|c|c|}
\hline Survey question & Education & $\mathbf{N}$ & $\ddot{\mathbf{X}}$ & SD & $\mathbf{F}$ & Sig. & Difference \\
\hline \multirow{3}{*}{$\begin{array}{l}\text { 1) Do you order } \\
\text { takeaway food (pizza, } \\
\text { lahmacun, doner } \\
\text { kebab)? }\end{array}$} & 1)primary school* & 105 & 3,87 & 0,38 & \multirow{3}{*}{3,684} & \multirow{3}{*}{0,025} & \multirow{3}{*}{$1>2,3$} \\
\hline & 2)high school* & 271 & 3,73 & 0,51 & & & \\
\hline & 3)university* & 882 & 3,8 & 0,49 & & & \\
\hline \multirow{3}{*}{$\begin{array}{l}\text { 2) How often do you } \\
\text { eat fast food? }\end{array}$} & 1) primary school* & 105 & 3,8 & 0,52 & \multirow{3}{*}{4,509} & \multirow{3}{*}{0,011} & \multirow{3}{*}{$1>2,3$} \\
\hline & 2) high school * & 271 & 3,6 & 0,66 & & & \\
\hline & 3) university * & 882 & 3,69 & 0,6 & & & \\
\hline \multirow{3}{*}{$\begin{array}{l}\text { 3) Do you buy bread } \\
\text { from the grocery or } \\
\text { bakery? }\end{array}$} & 1) primary school ${ }^{*}$ & 105 & 1,34 & 0,47 & \multirow{3}{*}{6,488} & \multirow{3}{*}{0,002} & \multirow{3}{*}{$1>2,3$} \\
\hline & 2) high school * & 271 & 1,18 & 0,39 & & & \\
\hline & 3) university * & 882 & 1,28 & 0,45 & & & \\
\hline \multirow{3}{*}{$\begin{array}{l}\text { 4) Do you consume } \\
\text { immune-boosting } \\
\text { foods (yogurt, kefir, } \\
\text { sources of vitamin c)? }\end{array}$} & 1) primary school & 105 & 1,74 & 0,94 & \multirow{3}{*}{0,646} & \multirow{3}{*}{0,524} & \multirow{3}{*}{ 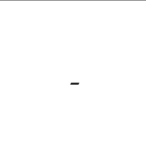 } \\
\hline & 2) high school & 271 & 1,8 & 0,93 & & & \\
\hline & 3) university & 882 & 1,73 & 0,92 & & & \\
\hline \multirow{3}{*}{$\begin{array}{l}\text { 5) Why do you skip } \\
\text { meals? }\end{array}$} & 1) primary school & 105 & 2,31 & 1,32 & \multirow{3}{*}{1,038} & \multirow{3}{*}{0,355} & \multirow{3}{*}{ - } \\
\hline & 2) high school & 271 & 2,16 & 1,2 & & & \\
\hline & 3) university & 882 & 2,28 & 1,29 & & & \\
\hline \multirow{3}{*}{$\begin{array}{l}\text { 6) Do you think you } \\
\text { have a balanced diet? }\end{array}$} & 1) primary school & 105 & 1,51 & 0,87 & \multirow{3}{*}{0,187} & \multirow{3}{*}{0,829} & \multirow{3}{*}{ - } \\
\hline & 2) high school & 271 & 1,55 & 0,89 & & & \\
\hline & 3) university & 882 & 1,56 & 0,9 & & & \\
\hline
\end{tabular}

Table 6 demonstrates whether the nutritional habits of the participants differed according to their educational background in the questions with the highest change. According to the table, the mean value differed in the first three questions. When the given differences were analyzed, it is worth noting that the mean values of the primary school graduates were higher than those of the high school and university graduates.

\section{Conclusion and recommendations}

As can be seen from the results presented in Table 2, given under the heading "Analysis and Findings", significant changes have occurred in the nutritional habits of consumers as a result of the extraordinary and unexpected situations caused by COVID-19. Among these changes, the highest one was seen in ordering takeaway food with $40 \%$. While the rate of not ordering takeaway was $43.5 \%$ before COVID-19, this rate has increased to $83.5 \%$ after COVID-19. This change may result from the hygiene sensitivity of the participants due 
to COVID-19 or from the restriction of the activities of the food and beverage businesses within the scope of the measures taken for COVID-19. In this process, consumers could be advised to give orders from businesses that they believe to comply with hygiene and cleaning rules and strictly follow the protective measures (isolation, social distance, non-contact, etc.) in the process of receiving orders and making payments. It is also recommended that the businesses that provide takeaway service should strictly follow all kinds of cleaning and hygiene rules under the extraordinary conditions we are in.

As can be seen in the same table (Table 2), the second biggest change in the ranking is observed in the question related to the fast food consumption habit. According to the results, while the rate of those who did not consume fast food before COVID-19 was $39.0 \%$, this rate climbed to $76.9 \%$ after COVID-19. The most important reason for this may be because of the healthy dietary tendency that emerged in the participants due to COVID-19. This is because it is frequently emphasized in the written and visual media that the most important defence against viruses during the COVID-19 process is strengthening the immune system, and the most effective way to achieve this is a balanced and healthy nutrition. Consumers may be advised to continue this positive situation after COVID-19, and to pay more attention to this issue especially in children in developmental ages. Based on the assumption that consumers will maintain this positive attitude after COVID-19, food and beverage businesses can be recommended to give prominence to healthy food types in their product range and draw consumers' attention to their sensitivity about balanced nutrition.

As can be seen in Table 2, the third biggest change in nutritional habits occurs in the habit of making bread at home with $21.1 \%$. While the rate of making bread at home instead of buying bread from the grocery or bakery was $5.7 \%$ before COVID-19, this rate increased to $26.8 \%$ after COVID-19. As mentioned above, this change may be due to the increased hygiene and cleaning sensitivity of the participants after COVID-19, or to the tendency to spend some time during the quarantine at home after COVID-19 and/or to return to traditional eating habits. In this process, consumers are advised to pay attention to safety rules as well as hygiene rules. Besides, they can be recommended to show the necessary sensitivity about the raw materials used in bread making (flour, yeast, sugar, salt, etc.) to be balanced and healthy in terms of nutrition and quantity.

The fourth biggest change in nutritional habits due to COVID-19 is observed in consuming immune-boosting foods with $13.2 \%$. The rate of the response option "Every day" given to the question "Do you consume immune-boosting foods (yogurt, kefir, sources of vitamin c)?" was 38.3\% before COVID-19, while this rate increased to $51.5 \%$ after COVID-19. This change may be caused by the participants' efforts to strengthen their immune system as a result of their 
healthy diet as well as their increasing sensitivity about cleaning and hygiene after COVID-19, as revealed in the questions "Do you order takeaway food (pizza, lahmacun, doner kebab)?" and "How often do you eat fast food?". When consuming immune-boosting foods, consumers are advised to take into consideration the suggestions of experts in this field, to buy the products of the companies that are inspected and produce at international standards, and to consume these foods in a balanced way. Otherwise, these foods that are consumed too much to strengthen the immune system may have unexpected negative results.

In addition, more than $10 \%$ change occurred in the questions "Why do you skip meals?" and "Do you think you have a balanced diet?", which were the last two questions in Table 2 given under the heading "Analysis and Findings". The rate of change that emerged in these questions was $13.2 \%$ and $12.0 \%$, respectively. The rate of one of the response options given to the question "Why do you skip meals?" appears to have declined after COVID-19. The decrease was in the response option "I don't have time", and the rate of the option, which was $28.9 \%$ before COVID-19, decreased to $15.7 \%$ after COVID-19. As in the first four questions, an increase was detected in the item related to having a balanced diet after the COVID-19. While the response rate of the option related to having a balanced diet was $59.9 \%$ before COVID-19, it rose to $71.9 \%$ after COVID-19. It can be considered that the change in both questions is positive, and meal skipping decreases thanks to the disappearing problem of not having time during home quarantine, and this will contribute positively to the balanced diet. It is expected that both these behaviours of the participants and the idea that they consume immune-boosting foods support their thoughts about eating healthily. Consumers are advised to continue this positive behaviour of theirs when this extraordinary situation goes away after COVID-19.

Table 3, given under the heading "Analysis and Findings", reveals whether the change in the nutritional habits of the participants differs by gender. In Table 3 and the following tables, the questions in which higher than $10 \%$ change occurred at the end of the analysis were taken into consideration. The table indicates that the questions "Do you order takeaway food (pizza, lahmacun, doner kebab)?", "How often do you eat fast food?" and "Do you buy bread from the grocery or bakery?" differ according to gender. In the light of the results of the analysis, it is understood that females had higher mean values than males in all three of these differences. This may be due to the fact that women are more sensitive than men in terms of both cleaning and hygiene and a healthy diet. It is recommended that food and beverage companies should emphasize behaviours that take into consideration this sensitivity of female consumers in particular. 
Table 4 illustrates whether there is a difference in the nutritional habits of the participants based on their age in the questions with the highest change. According to the table, the nutritional habits of the participants differed based on their age in the five questions except the question "Do you buy bread from the grocery or bakery?". When these mean differences are examined, it is noteworthy that consumers in the 18-35 age range had a higher mean than those in other age groups in the items related to ordering takeaway food, consumption of fast food and having a balanced diet. In the question "Why do you skip meals?", it is observed that the participants aged 18-35 years had a higher mean value than those between 36-50 years old. In addition, in the question "Do you consume immune-boosting foods (yogurt, kefir, sources of vitamin c)?" contrary to other age groups, it can be seen that the mean value of those aged 50 and above had a higher mean value compared to other age groups. Moreover, in the questions "Do you order takeaway food (pizza, lahmacun, doner kebab)?", "How often do you eat fast food?" and "Do you think you have a balanced diet?", the higher mean of the people aged between 18 and 35 years may be related to the possibility that these actions were higher before COVID-19. The same situation could be valid for the question "Why do you skip meals?". Consumers may be advised to continue these positive behaviours under normal circumstances.

Table 5 shows whether the nutritional habits of the participants differ according to their income level in the questions with the highest change. As can be seen from the table, such a difference is only observed in the questions "How often do you eat fast food?" and "Do you think you have a balanced diet?". The analyses of these questions indicate that the mean values of those who did not have any income were higher than those who had an income of $5000 \mathrm{TL}$ and above in the first question and the mean values of those who did not have any income were higher than others in the latter. It can be thought that the frequency of eating out for those who have no income is low because of their financial conditions and because they traditionally cook and eat at home most of the time. It is recommended that food and beverage businesses include products that will meet the expectations of this group in their menus and develop a promotional effort that will draw the attention of this group in their marketing activities.

Table 6 demonstrates whether the nutritional habits of the participants differ according to their educational background in the questions with the highest change. According to the table, the mean values differed in questions "Do you order takeaway food (pizza, lahmacun, doner kebab)?", "How often do you eat fast food?" and "Do you buy bread from the grocery or bakery?". The analyses of the differences point out that primary school graduates had a higher mean than high school and university graduates. This difference may be due to the same reason as in the one based on income. The reason for this is considered to 
be the fact that the income level of primary school graduates is likely to be lower than that of the high school and university graduates. Therefore, the suggestion made above for food and beverage businesses is also valid for this situation.

Since the study was conducted during the extraordinary conditions we are in, researchers may be offered to compare results by carrying out similar studies when the conditions get normal. In addition, it can be recommended that researchers evaluate the similarities and differences by comparing their studies with the ones conducted abroad.

\section{References}

Acar, Y. (2020). Yeni covid-19 virus (covid-19) salgını ve turizm faaliyetlerine etkisi. Güncel Turizm Araştırmaları Dergisi, 4(1), 7-21.

Akpınar, F. \& Üstün, Y. ( 2020). Kadın hastalıkları ve doğum pratiğinde sarscov-2 (covıd-19) enfeksiyonu ile ilgili güncel bilgiler. Türk Kadın Sağhlğg ve Neonatoloji Dergisi, 2 (1), 13-16.

Altunışık, R., Coşkun, R., Bayraktaroğlu, S. \& Yıldırım, E. (2007). Sosyal bilimlerde araştırma yöntemleri: Spss uygulamalı. Sakarya Yayıncılık

Arslan, M. (2018). Beslenme alışkanlıkları ve fiziksel aktivite düzeylerinin analizi: Marmara üniversitesi öğretim üyeleri üzerine bir çalışma. Dicle Tıp Dergisi, 45 (1), 59-69.

Astarlı, Ö. (2008). Marmara üniversitesi tıp fakültesi 1. ve 5. sinı öğrencilerinde beslenme bilgi düzeylerinin ve beslenme alışkanlıklarının değgerlendirilmesi (Master's thesis). Marmara University.

Atkinson, R. L., Atkinson R. C., Smith, E. E. \& Hoeksama, S.N. (1999). Psikolojiye Giriş. Arkadaş Yayınları.

Babicz-Zielińska, E. Rybowska, A. \& Rybowska, R. (2006). Relations between emotions and food preferences. Polish Journal of Food and Nutrition Sciences. 15(56), 163-165.

Baltaş Z. and Baltaş, A. (2000). Stres ve başa çıkma yolları. Remzi Kitabevi.

Born, J., Lemmens, S., Rutters, F., Nieuwenhuizen, A.G., Formisano,E., Goebel,R. et al. (2010). Acute stress and food-related reward activation in the brain during food choice during eating in the absence of hunger. International Journal of Obesity. 34, 172-181.

Büyüköztürk, Ş. (2010). Sosyal bilimler için veri analizi el kitabı. Pegem Yayınları.

Culbert K.M. Racine S.E. \& Klump K.L. (2015). Research review: what we have learned about the causes of eating disorders - a synthesis of sociocultural, psychological, and biological research. The Journal of Child Psychology and Psychiatry. 56(11), 1141-1164. 
Çetinkaya, A. (2010). Kafkas üniversitesi öğrencilerinin içme sütü ve süt ürünlerini tüketim alışkanlıklarının belirlenmesi. Atatürk Üniversitesi Veteriner Bilimleri Dergisi. 5 (2), 73-84.

Çokluk, Ö.,Şekercioğlu, G. \& Büyüköztürk, Ş. (2010). Sosyal bilimler için çok değişkenli istatistik spss ve lisrel uygulamaları. Pegem Akademi.

Davison C.D. \& Neale J.M. (2005). Abnormal psychology . Wiley: John Wiley \& Sons, Inc.

Kahraman, Ç. (2018). Üniversite öğrencilerinde beslenme alışkanlıkları ve obezite riski: Tekirdă̆g namık kemal üniversitesi örneği (Master's thesis). Namık Kemal University.

Kandiah, J. Yake, M. Jones, J. \& Meyer, M. (2006). Stress influences appetite and comfort food preferences in college women. Nutrition Research, 26(3), 118-123.

Ministry of İnterior (2020). Press brifing. Retrieved from https://www.icisleri. gov.tr/sehir-giriscikis-tebirleri-ve-yas-sinirlamasi

Onurlubaş, E. \& Çakırlar, H. (2016). Tüketicilerin süt ve süt ürünleri tüketimini etkileyen faktörlerin belirlenmesi üzerine bir araştırma. Çankırı Karatekin Üniversitesi Sosyal Bilimler Enstitüsü Dergisi. 7(1), 217-242.

Ovalı, F. (2020). Yenidoğanlarda covıd-19 enfeksiyonları. Anadolu Klinĭği Tıp Bilimleri Dergisi. 25(özel sayı 1), 25-35.

Paeratekul, S. Ferdinand, D. Champagne, C. Ryan, D. \& Bray, G. (2003). Fastfood consumption among us adults and children: dietary and nutrient intake profile. Journal of the American Dietetic Association. 103(10),1332-1338.

Penaforte, O. F. Matta, N. C. and Japur, C. C. (2016). Association between stress and eating behaviour in college students, Demetra: Food, Nutrition $\mathcal{E}$ Health. 11(1), 225-237.

Rozin, P. Levine, E. \& Stoess, C. (1991). Chocolate craving and liking, Appetite. 17(3), 199-212.

Saygın M, Öngel K, Çalışkan S, Yağlı M, Has M, Gonca T. et al. (2011). Süleyman demirel üniversitesi öğrencilerinin beslenme alışkanlıkları, SDÜ Tıp Fakültesi Dergisi.18 (2), 43-47.

Shepherd, R. \& Dennison, M. C. (1996). Influences on adolescent food choice. Proceedings of the Nutrition Society. 55(18), 345-357.

Stein, K. (2008). Contemporary comfort foods: bringing back old favorites. Journal of the American Dietetic Association. 108(3), 412-414. 
Şen, M.A. (2020). Koronavirüs (covid-19) salgınının türkiye'deki yemek firmalarında oluşturduğu etkinin belirlenmesi üzerine bir araştırma. Afet ve Risk Dergisi. 3 (1), 89-100 .

Tryon, M. S. DeCant, R. \& Laugero, K. D. (2013). Having your cake and eating it too: a habit of comfort food may link chronic social stress exposure and acute stress-induced cortisol hyporesponsiveness, Physiology $\mathcal{E}$ Behaviour. 114-115, 32-37.

Unur, K. \& Gök. D.K. (2012). Tüketicilerin tez yemek tüketme nedenleri: mersin şehir merkezinde faaliyet gösteren yerel, ulusal, uluslararası zincir yemek işletme müşterileri örneği. Balıkesir Üniversitesi Sosyal Bilimler Enstitüsü Dergisi. 15(27), 357-368

Ural, A. \& Kılıç, İ. (2005). Bilimsel araştırma süreci ve spss ile veri analizi. Detay Yayıncilik.

Vabo, M. \& Hansen, H. (2014). The relationship between food preferences and food choice: A theoretical discussion. International Journal of Business and Social Science. 5(7), 145-157.

Wansink, B. Cheney, M. M. \& Chan, N. (2003). Exploring comfort food preferences across age and gender. Physiology E Behaviour. 79(4-5), 739747.

Yöndem, Z. (2006). Kişilik dinamikleri ve stresle başa çıkma. Morpa Kültür Yayınlar.

Zellner D.A., Loaiza S., Gonzalez Z., Pita J., Morales J., Pecora D. et al. (2006). Food selection changes under stress. Physiology E Behaviour. 87(4), 789793.

\section{Ethical approval}

This study has been approved by the Scientific Research and Publication ethic committee of Giresun University with 11 May 2020, meeting 44079388-38 and decision 2020-2 number and date.

\section{Contribution rate of researchers}

The authors contributed equally to the study.

\section{Conflict of interest}

There is no potential conflict of interest in this study. 
